As for de Grazia's parting quip, I can only reply by refusing to hold myself accountable for what some of my readers may wish.

Ronald Levao

Princeton University

\section{Trakl and Chinese Poetry}

To the Editor:

Pauline Yu's intriguing article on the "East-West Correspondences in Lyric Poetry" (PMLA, 94 [1979], 261-74) points to hitherto unfamiliar aspects of Trakl's poetry, unfamiliar at least to the Germanist. Therein lies its strength but also its weakness. Strangely, Yu does not once mention the term "expressionism." Rather, she refers to Georg Trakl somewhat blandly as a "post-Symbolist." It would seem that, however we define expressionism, Trakl's formal and thematic identification with that style is evident; he shares with the other poets of expressionism the many features singled out by $\mathrm{Yu}$ (e.g., parataxis, "ciphers," end-stopped lines, the juxtaposition of nouns). While Trakl's poetry lacks the pathos characteristic of the later expressionists who struggled against the forces that threatened to enslave mankind and who issued a call for the rebirth of man, he was certainly one of the early poets of the group. Moreover, the expressionists are linked to the romanticists through the visionary aspects of both movements. Trakl's poetry, therefore, cannot simply be considered in isolation, as if the poet just happened to be a kindred spirit of the poets of the T'ang Dynasty of a thousand years ago. The "discontinuity" of language present in Yu's Chinese examples and the corresponding quality in Trakl's poems have different origins. The distrust of traditional language, the need to express a vision of the essence of man, and the view of reality as chaos were born of a historical development with which the expressionist poets were confronted at the beginning of the twentieth century. Their perception of the human condition led them to employ new or uncommon poetic means, such as abstraction, the omission of any reference to a speaker or the use of the collective "we" in place of the personal "I," typecasting, and mythologizing. Their ultimate aim was the poetic realization of the rebirth of man.

$\mathrm{Yu}$ points to the similarities in syntax and imagery between Chinese poetry and Trakl's and states that the classical Chinese language tends very much toward syntactic discontinuity (pp. 262-63). Since German, however, does not have that tendency (or a tradition of writing poetry in a paratactic style, as $\mathrm{Yu}$ says ancient Chinese poetry does [p.
262]), the discontinuity of Trakl's language must be contrived. The correspondences in the two sets of poems, therefore, appear to be accidental rather than historical; as $\mathrm{Yu}$ remarks, Trakl sought the effect of Chinese poetry because it suited his purposes. He and the other expressionists share the technique of using parataxis, for example, or of attaching absolute value to objects. In this respect, then, Pauline Yu's parallels, including the parallel of impersonality, are instructive but misleading. The world view of Trakl specifically and that of the expressionists as a group encouraged "generality," that is, a highly subjective view of man against the backdrop or foil of a seemingly objective style.

Finally, a word about Pauline Yu's translations from the German. They are on the whole felicitous and betray a good feel for the Ianguage. Still, there are errors that matter, because in poetry, especially, every word is important: p. 261 et passim: Weiher = "fish pond" (not "weir"); p. 267: Gewaltig = "mightily" (not "peacefully"); verbrennen="to be consumed by fire," "to burn up" (not just "burned"); Hïgel = "hill" (not "hillock"); Kahn $=$ "boat," one of no particular description (unlike "skiff"); p. 268: Grauer = misprint for Trauer?; p. 270: ein Sterbliches = "something mortal" (not "a mortal") and hence the next line should be "something else suffers also" (not "and another suffers in sympathy"); p. 271: Des Menschen goldnes Bildnis = "man's golden image" (not "That man's golden image").

Again, Yu's article, though an unusual and instructive piece, lacks the historical dimension that would have given it a much stronger base than merely the Rilke reminiscence about Trakl and LiTai-Pe (p. 273, n. 1).

\section{Arthur Tilo Alt}

Duke University

\section{To the Editor:}

Pauline Yu's "The Poetics of Discontinuity: EastWest Correspondences in Lyric Poetry" offers a useful consideration of Symboliste and Imagiste poetry in terms of Chinese poetics, but it confounds Symbolisme and Imagisme. Ezra Pound insisted that "Imagisme is not Symbolisme" and that the "Image is not a symbol." The distinction, which is real and significant, should be noted in this context.

$\mathrm{Yu}$ pictures a poet attempting to achieve timelessness by arranging representative ciphers from an internal landscape. While this picture seems just for the Symboliste, Imagisme is in opposition to each of these points. 
Symboliste poetry is founded in an Idealist metaphysic, and its solipsism accords well with that view. A poet who believes that passing moments and external objects are delusions, mere shadows of Reality, cannot use them as materials for serious art. He is trapped inside his skull, or at least within his private landscape.

Given the use of a new metaphysic represented by the metaphor of a dynamic spiral connecting external reality with internal reality in unending process, Pound and his Imagiste colleagues could escape the solipsism to which the Symbolistes and the Decadents had been damned. (Pound and Joyce wrote of poètes maudites with respect, compassion, and a corresponding sense of their own freedom.) The common view of the Imagiste poem as static and neglectful of verbs is mistaken. In the essay published as "Vorticism" but written under the title "Imagisme," Pound wrote:

The image is not an idea. ... It is . . a vorTl.x, from which, and through which, and into which, ideas are constantly rushing. In all decency one can only call it a vorTex. [emphases Pound's]

He defined the image, not as a "timeless moment of revealed truth" (YLI, p. 263), but as a complex that gives a "sense of freedom from time limits and space limits; that sense of sudden growth ..." (quoted by $\mathrm{Yu}$, p. 264; my emphasis). The Imagistes were freed to try for a poetry that could escape the limits imposed by our usual concepts of space and time-including the assumptions that measurement is fundamentally useful and that "time" presupposes linear forward movement. This poetry was based on a respect for the reality and value of process, of becoming, and thus of time.

The meaning of "Intuition," invoked by Yu to explain our ability to relate elements presented in paratactic juxtaposition, is not the same for an Imagiste and a Symboliste. For the latter, "Intuition" had been a contact with the Eternal. For the former, who had the use of William James's new psychology, "a feeling of and, a feeling of if, a feeling of but"1 were the concrete products of a process inherent to our nervous system, an aspect of the interaction between internal and external actualities. "The natural object is always the adequate symbol," says the Imagiste manifesto. Pound's "natural object" is objective: it originates in nature, not in any Ideal landscape. The Imagiste manifesto calls for "presentation," as opposed to representation. "When I say "cat," Pound insists, "I mean CAT." Charles Tomlinson was speaking in the influential tradition stemming from Pound and his Imagiste confreres when he told me, "Your crow cannot symbolize death unless it has real, black feathers and a believable caw."

Yu says of Li Ho's "Northern Cold" and Georg Trakl's "Im Winter" that "the poet is providing us with some arbitrarily assembled elements" (p. 262; emphasis mine), and she quotes Frodsham as saying that $\mathrm{Li}$ Ho would "jot down lines and phrases as they occurred to him and then piece them together like a mosaic on his return home" (p. 262; emphasis Yu's). She says further, "In "Northern Cold" . . there appears to be no linear progression, no necessary order to the sequence of lines. Li Ho's gaze shifts about with no discernible logic. . .." In Li Ho as well as in Trakl, "each line, then, could have appeared in a different position in the poem" (p. 262; emphasis mine )

It is important to recall, however, that "arbitrary" means "subject to judgment" or "resulting from decision(s)" and that the essence of mosaic is the arrangement of elements into patterns. In "Konstellationen," the "mutual relationship" of elements (noted by Gomriger as quoted by $\mathrm{Yl}$, p. 273) arises not only through their "material, concrete presence in the same space" but also through their arrangement in that space. A poet can control a developing image by ordering the presentation of its parts. If the lines were rearranged, we should have different poems.

Within a framed scheme of increasing dynamism and threat, $\mathrm{Li}$ Ho gains coherence by adjoining thematically parallel elements. "Northern Cold" is framed by the static lines 1 and 8 , which the translator renders without verbs until he leaves line 8 hanging on the verb "hang." In contrast to the verbs of lines 3-5, those of line 2, which deals with the death of animals, do not imply articulated process. Lines 3-5 present crackling patterns in inanimate solids ("tree bark," "river ice," "frost") subject to measurement ("three feet," "hundred-picul," "large as copper coins"). Lines 6-7 share the themes of aggression against an amorphous opponent (e.g., "brandished swords ... misting sky"). Finally, the "flying foes clamor" concluding line 7 provides a transition to the "Mountain waterfalls soundless" that opens the final line; these images are so mutually resonant that they could function in a single haiku.

As if to demonstrate that poctic pattern and "necessary order" can be achieved by other than logical means, by other than "linear progression," "Im Winter" progresses through points of visual focus. The poem's gaze cycles between objects seen by looking $u p$ and those seen by looking down. In a cross-rhythm are shifts between looking in 
and looking out (at close objects and at distant ones). Words like "circle," "descend," "rises" direct and reinforce the movement. As the reader can confirm by imaginatively tracking the objects in Trakl's order, the resulting pattern is that of a spiral. Passing through a series of visual foci, that coil repeatedly connects a chill and merciless heaven with a chill and merciless earth. All the whileagain in contrast to "Northern Cold"- the objects viewed are never subjected to measurement.

All this can be dramatized by rearranging the lines of "Im Winter" so that "up" lines are sorted out from "down" lines and juxtaposed, with a change also in the "in-out" pattern; lines 1 and 12 keep their positions, and the punctuation is unchanged:

\author{
The field glimmers white and cold. \\ And ravens splash in bloody ditches. \\ Reeds tremble yellow and tall. \\ A deer bleeds to death gently on the ridge
}

And the gray moon rises slowly.

The sky is lonely and monstrous.

A silence dwells in black rooftops.

Jackdaws circle over the weir

Sometimes afar a sleighbell rings

And hunters descend from the wood.

A fire's gleam slips from the huts;

Frost, smoke, a step in the empty grove.

This piece, both more grim and more optimistic than "Im Winter," is not Georg Trakl's poem.

LAYEH A. Bock

Stanford University

1 The Principles of Psychology (New York: Holt, 1890), p. 245.

\section{"Voice" in As I Lay Dying}

To the Editor:

I was so struck by the reasoning that undergirds Stephen M. Ross's essay " 'Voice' in Narrative Texts: The Example of As I Lay Dying" (PMLA, 94 [1979], 300-10) that I feel compelled to comment on it. In confining his exploration of the term "voice" to As I Lay Dying, Ross cleverly evades a number of the more problematic uses of this term as a critical tool (i.e., as applied to "impersonal" narratives), and yet the backdrop of his examination would seem to push both author and reader to a consideration of the efficacy of this term even in response to such a text as Faulkner's, which on the surface suggests its applicability.
Ross begins by hinting that the "ordinary" use of "voice" connects it with "vocal sound as the vehicle of human utterance or expression"; he then suggests that there exists a figurative use of "voice" (unspecified, except by reference to a series of critical works that apparently employ it [n. 4, pp. 308-09]) whose origins in critical dialogue are already receding into the darkness of memory, leaving behind a residue of critical "misuse" of this term. While it would seem to be the function of this essay to "pry loose" some of the figurative applications of "voice," the discussion directs itself toward refuting the use of this word in its more ordinary context, as an extension of human consciousness, using $A s I$ Lay Dying as a pretext for demolishing what might scem to be an almost perversely literal-minded application of a critical tool.

The approach is clearly structuralist, and therefore the crux lies in language itself: works of fiction are (we now know) nothing more than words, but it has been traditional, unfortunately, to assume that such words issue from a voice that itself "presumably emanates from someone, though the source may be hidden or unnamed" (p. 300). This assumption is provably incorrect (in regard to Faulkner's text, at least), as Ross demonstrates: "Critics discover discourse they cannot believe: Vardaman, the littlest Bundren, speaks of his brother's horse as 'an unrelated scattering of components-snuffings and stampings; smells of cooling flesh and ammoniac hair'. . . The objection raised here is very simple. Vardaman as a person could not talk this way; therefore he is poorly employed as a narrator" (p. 302).

If the reader is naïve enough to search for an author behind Vardaman, an entity responsible for "raising" the level of this particular discourse beyond the childlike, one discovers another impediment to critical evaluation: "even when no such entity as an author can be discovered, we still try to identify 'him' in a speech implying human origin somewhere just over the horizon of the imagined world" (p. 305) - and to no avail, presumably, since "if As I Lay Dying does lead the reader to seek an author, it does not do so as a means of anchoring voices in the 'presence' of an author; the author, like the narrator, is constituted by mimetic voice, and the paradox of fictional representation remains unsolved" (p. 305).

Another detour one might follow in an effort to discover the human arena for the "voice" we hear leads to an exploration of the consciousness of the characters, specifically that which involves "interior monologue," expressed in thought rather than in speech. But this too leads to a dead end: "a strict application of the term 'interior' presupposes a 